\title{
Psykiatrisk epidemiologisk forskning i Tromsø
}

\author{
Vidje Hansen*, Reidun Olstad* og Odd Nilssen** \\ *Avdeling for klinisk psykiatri, Institutt for klinisk medisin, Det medisinske fakultet, Universitetet i Tromsø \\ **Seksjon for sosialpsykiatri, Institutt for samfunnsmedisin, Det medisinske fakultet, Universitetet i Tromsø
}

\section{SAMMENDRAG}

\begin{abstract}
Artikkelen beskriver den psykiatriske epidemiologiske forskningen i Tromsø siden 1990. Man har arbeidet mest innenfor rammen av store helseundersøkelser av den generelle befolkningen slik som Tromsøundersøkelsene, som omfatter fra 6000 til mer enn 20000 personer undersøkt 5 ganger i perioden 1974-2001 og Finnmarksundersøkelsene, som er gjort 6 ganger på omtrent like mange personer og i løpet av samme tidsperiode. Disse undersøkelsene har vært utført i et samarbeid mellom Institutt for Samfunnsmedisin og Statens Helseundersøkelser. Man har kunnet studere psykiske plager og alkoholforbruk målt ved noen få spørsmål hentet fra større spørreskjema, og analysert slike plager i relasjon til ulike risikofaktorer både i tverrsnitts-studier og prospektivt. I tillegg har det vært gjennomført flere enkeltstående epidemiologiske undersøkelser i ulike populasjoner. Disse har generelt hatt et noe smalere fokus: psykiske plager, vinterdepresjon, søvnplager i mørketiden, og rusmiddelbruk. I tillegg til populasjoner i Norge har det vært gjort studier på Svalbard og i Arkangelsk i Russland. Det er også bygget opp et psykiatrisk register over alle personer og innleggelser ved Åsgård sykehus, som går tilbake til 1980. Opptaksområdet for avdelingen er 225000 mennesker, og registeret har vært brukt til ulike formål, bl.a. koblinger til andre registre, som Dødsårsaksregisteret og Medisinsk Fødselsregister. Resultatene fra disse ulike studiene refereres kort, og det trekkes opp noen fremtidige perspektiver for psykiatrisk epidemiologi i Nord-Norge.
\end{abstract}

\section{INNLEDNING}

Ved etableringen av Universitetet i Tromsø tidlig på 1970-tallet ble den akademiske voksenpsykiatrien knyttet til Institutt for samfunnsmedisin, ISM. Dette instituttet har gjennom de 30 årene det har eksistert, bygget opp et sterkt generelt epidemiologisk miljø med tilhørende ekspertise i statistikk og EDBfunksjoner, og har gjennom årene hatt ansvaret for gjennomføringen av mange store generelle helseundersøkelser av befolkningen i Nord-Norge, i Russland og $i$ enkelte utviklingsland. Det har derfor vært naturlig at mye av den psykiatriske forskningen som har funnet sted i løpet av disse 30 årene har tatt utgangspunkt i epidemiologiske problemstillinger i disse generelle befolningsstudiene. Flere studier ledet av ikke-psykiatere har hatt mental helse inne som delaspekter, men vi har her begrenset oss til å beskrive den forskningen som i hovedsak har vært drevet av psykiatere og hvor psykiatriske problemstillinger har vært hovedfokus for prosjektene. Avgrensningen mellom epidemiologisk forskning og helsetjenesteforskning har også vært vanskelig å foreta, men vi har valgt å ikke ta med de prosjektene som har vært mest utpreget helsetjenesteforskning. Vi har også begrenset oss til voksenpsykiatriske prosjekter.

Vi vil først gi en oversikt over de datamaterialer som har vært utgangspunkt for de epidemiologiske studiene, dernest presentere hovedkonklusjonene fra studiene, for til slutt å diskutere status og idéer om fremtidig epidemiologisk psykiatrisk forskning i Tromsø.

\section{MATERIALER OG METODER}

\section{Helseundersokelsene i Tromso og i Finnmark 1974- 2001}

I tidsrommet 1974-2000 er det gjennomført til sammen 5 store helseundersøkelser i Tromsø kommune og 6 i Finnmark fylke. Disse har vært et samarbeid mellom ISM og Statens Helseunders $ø$ kelser, SHUS. Unders $\varnothing-$ kelsene er spørreskjemabaserte kombinert med fremmøte der somatiske tilleggsundersøkelser er utført. Dataene er personidentifiserbare og undersøkelsene er delvis utført på de samme individene fra gang til gang, slik at det er mulig å gjennomføre prospektive studier ved kobling av flere undersøkelser, i tillegg til å bruke undersøkelsene som repeterte tverrsnitts-studier. Undersøkelsene hadde de første årene i hovedsak hjertekar-lidelser som klart hovedsiktemål, men kom snart til å omfatte en rekke andre helsevariabler. Foruten slike som er nært relatert til hjerte-kar-lidelser, som alkoholforbruk, røyking, og fysisk aktivitet, tok man inn psykiske plager, livskvalitet, sosialt nettverk, bruk av ulike medikamenter, muskel-skjelettsykdommer og lignende. Studiene har også variert i forhold til hvilken populasjon som er innkalt på de forskjellige tidspunktene. I Tromsø II (1980) og III (1986) var det over 20000 innkalte, og i Finnmark III (1987) var det ca. 23 000. Finnmarksundersøkelsene er beskrevet $i$ et eget nummer av ISMs skriftserie ${ }^{1}$. Fremmøteprosenten har gjennomgående vært svært god, fra over $80 \%$ i de første undersøkelsene, men noe synkende etter hvert. Når det gjelder indikatorer på psykiske plager, har dette vært noen få spørsmål hentet fra 20 -items utgaven 
av "The General Health Questionnaire" ${ }^{2}$, supplert med spørsmål om årstidsvariasjoner i psykisk helse, bruk av psykofarmaka, bruk av psykiatrisk helsetjeneste, med mer. Spørsmålene har i hovedsak vært holdt konstante gjennom alle de ulike undersøkelsene, noe som er en klar styrke metodologisk.

\section{Pasientregister for Åsgård sykehus}

Åsgård sykehus er den eneste psykiatriske avdelingen på 3de-linje nivå for befolkningen i Troms og Finnmark, som omfatter ca. 225000 innbyggere. Det pasientadministrative registeret over innleggelsene ved sykehuset fra 1980 og foreløpig ut 1995, er blitt gjennomgått mht. fullstendighet og reliabilitet. Databasen dekker foreløpig alle innleggelser i 16 år, noe som utgjør nesten 3000 enkeltpersoner og over 8000 innleggelser. Vi kan da analysere både med innleggelse som enhet, og med enkeltpersoner som enhet, og følge enkeltpersoner gjennom alle sine innleggelser. I epidemiologisk øyemed har registeret foreløpig vært brukt til koblinger med Tromsø-undersøkelsen, Dødsårsaksregisteret i Norge, og med Medisinsk Fødselsregister. Det skal nå oppdateres for perioden 1996-2001, og vil så bli holdt løpende oppdatert.

\section{Svalbardundersokelsene}

I 1988-89 inngikk den norske befolkning på Svalbard i en tverrsnittsundersøkelse, og 3 år senere ble denne undersøkelsen repetert på den russiske befolkningen. Den første undersøkelsen ble foretatt av ISM i samarbeid med SHUS og helsetjenesten på Svalbard ${ }^{3}$. Den andre var et samarbeid med Universitetet i Arkhangelsk i Russland. Undersøkelsene var svært lik Tromsøundersøkelsene, i tillegg ble det inkludert en del "Svalbardspesifikke" spørsmål, inklusive sesongrelaterte psykiske tilstander. I alt ble vel 600 nordmenn (75\% av de inviterte) og 450 russere ( $95 \%$ av de inviterte) inkludert i studien. Studien fokuserte på flere områder, i psykiatrisk sammenheng kan nevnes psykiatrisk morbiditet, alkoholkonsum og vinterdepresjon (seasonal affective disorder, SAD) og søvnvansker. Alkoholkonsumet ble undersøkt ved spørreskjema og ved biologiske markører i blod. Videre innhentet man detaljert informasjon om salg av alle typer alkohol til fastboende på Svalbard. I tillegg til generelle spørsmål om psykisk helse besvarte samtlige GHQ-20.

\section{Arkhangelskundersokelsen}

Bakgrunnen for studien i Arkhangelsk var den dramatiske reduksjonen i levealder man har sett i Russland de siste 10 år. I nordvest-Russland har denne reduksjonen vært enda mer fremtredende enn for resten av landet, for enkelte etniske grupper har levealderen vært under 40 år. Økning av mortalitet relatert til hjerte-karsykdommer, død av unaturlige årsaker og økt alkoholkonsum i befolkningen har vært fremhevet som hovedforklaringer til denne endringen.
Vel 4000 menn og kvinner, rekruttert fortløpende fra en av de medisinske poliklinikkene i Arkhangelsk, deltok i studien i 1999-2000. Dette var en tverrsnittsstudie med fokus på sammenhengen mellom alkoholkonsum og generell helse i befolkningen, og var et samarbeid mellom ISM og Universitetet i Arkhangelsk. I tillegg til en bredt anlagt fokusering på hjertekar-sykdommer ble det også innhentet informasjon om alkoholkonsum, enkelte psykiatriske lidelser og lysmørke relaterte lidelser. Alkoholvariablene omfattet spørsmål om volum og frekvens av drikking, standardiserte spørreskjema, og biologiske alkoholmarkører.

\section{Skadeepidemiologi og alkoholforbruk}

Under et forskningsopphold i USA fikk en av oss (Nilssen), anledning til å være med i en studie ved Harborview Medical Center i Seattle. Her ble samtlige pasienter (2582 menn og kvinner) som ble innlagt i en kirurgisk akuttavdeling med stump eller penetrerende skade over en viss periode inkludert. Skadenes omfang ble beskrevet på standardisert måte, og tiltaksprosedyrer, liggetid og behandling ble registrert sammen med demografiske data. Flere standardiserte spørreskjemaer for alkoholforbruk og biologiske markører inngikk i undersøkelsen. Hovedfokus var sammenhengen mellom skade og alkoholforbruk, sammenhengen mellom ulike instrumenter for kvantifisering av alkoholforbruk, samt etablering av et nytt slikt instrument.

\section{Mindre befolkningsundersokelser}

I samarbeid med seksjon for generell epidemiologi ved ISM har det vært gjort to befolkningsundersøkelser med relevans for vinterdepresjon. I Sør-Varanger kommune ble alle mellom 18 og 69 år tatt med i en undersøkelse av luftforurensing, og spørsmål om sesongrelaterte plager ble inkludert. Nesten 4000 mennesker deltok. En undersøkelse i Gamvik på $70{ }^{\circ} \mathrm{N}$ er gjennomført og er under utskriving. Dette var en befolkningsundersøkelse av hjerte-kar-sykdommer i samarbeid med SHUS, men man tok også inn vinterdepresjon (SAD). Dette ble målt med et standardisert spørreskjema for depresjon, og subjektene fylte ut the Seasonal Pattern Assessment Questionnaire (SPAQ) 4 ganger, én i hver av de 4 årstidene, og man målte melatoninkonsentrasjonen $\mathrm{i}$ spytt på de samme 4 tidspunktene.

\section{ReSUlTATER}

Vi har valgt å presentere resultatene av den forskningen som har vært gjort i noen få hovedområder.

\section{Forskningsmetodologi}

Vi har gjort en psykometrisk studie av metoden med å trekke ut noen få spørsmål fra GHQ-20 for å få et mål for psykiske plager, slik det har vært gjort i mange av våre befolkningsundersøkelser. I to forskjellige materi- 
aler med over 2000 personer analyserte vi korrelasjonene mellom full score på 20 spørsmål, og forskjellige utvalg av 4 og 6 spørsmål fra det samme skjemaet ${ }^{4}$. For alle utvalgene var korrelasjonen svært høy, og økning fra 4 til 6 spørsmål ga svært liten økning av korrelasjonen. $\mathrm{Vi}$ argumenterer derfor for at noen få relevante spørsmål er tilstrekkelig til å måle graden av psykiske plager i befolkningsundersøkelser. For å identifisere tilfeller med definitive psykiske lidelser er slike metoder imidlertid ikke adekvate.

I Gamvik-studien har vi vist at prevalensen av $\mathrm{SAD}$, målt med SPAQ, i befolkningen ikke samvarierer med sesongvariasjoner i dagslysmengde, slik den etter teorien for årsakene til SAD skulle gjøre. Skåringene ga heller ikke uttrykk for subjektenes vanlige plager om vinteren, men var i stedet sterkt avhengig av når på året SPAQ ble fylt ut. Undersøkelser av vinterdepresjon må derfor ta høyde for dette, og rapportere på hvilken tid på året SPAQ er fylt ut. Dette svekker både validiteten og reliabiliteten av SPAQ betydelig ${ }^{5}$.

Ved en kobling mellom pasientregisteret for Psykiatrisk Avdeling og Tromsø II, kunne vi se på prevalensen av alvorlig psykisk lidelse hos de som møter til en generell helseundersøkelse, sammenlignet med de som ikke møter ${ }^{6}$. Vi viste at prevalensen av slik lidelse var 2,5 gang så høy hos de som ikke møtte. Lav alder, sivilstand enslig, schizofreni og alkoholmisbruk var signifikante prediktorer for manglende frammøte. Dette medfører en betydelig undervurdering av prevalensen av alvorlig psykisk lidelse i befolkningen, slik det framkommer i store befolkningsundersøkelser.

\section{Studier basert på pasientregisteret for Åsgård sykehus}

Vi har studert praksis mht. å sette schizofrenidiagnose i et materiale av førstegangsinnlagte ved Åsgård sykehus i perioden $1980-1995^{7}$. Vi kunne vise at det tok signifikant lenger tid for kvinner enn for menn å få schizofrenidiagnose. I epidemiologisk sammenheng har dette betydning for insidens-studier av schizofreni som baserer seg på førstegangsinnleggelser, hvor insidensen hos kvinner derved blir undervurdert.

I to publikasjoner ${ }^{8,9}$ har vi sett på mortalitetsmønsteret hos psykiatriske pasienter, ved kobling mellom pasientregisteret og Dødsårsaksregisteret i Norge. Det ble også gjort rekalkulasjoner og sammenligninger med mortaliteten i Norge tidligere, slik det er rapportert fra Sentralregisteret for psykoser. Mortaliteten var høyest for menn i alle diagnostiske grupper, og i det første året etter utskriving. Dødeligheten hos pasientene var 2-3 ganger så høy som $\mathrm{i}$ totalbefolkningen for totale dødsårsaker, og fra 0,9 for kreftdød til 36,3 for død ved selvmord. Sammenligning med psykiatriske pasienter i Norge i perioden 1963-74 viste at dødelighetsraten for menn har steget etter 1980, og overdødeligheten har steget for begge kjønn, særlig for selvmord. Resultatene blir diskutert i lys av deinstitusjonaliseringen i Norge som startet tidlig på 1980-tallet.

\section{Risiko- og beskyttelsesfaktorer for utvikling av psykisk helse}

\section{Tverrsnitts-studier}

Vi har studert risikofaktorer for lettere psykiske plager i materialet fra Tromsø II. Spørreskjemaet ble fylt ut av mer enn 14000 mennesker. Som indikatorer på psykiske plager hadde vi tre spørsmål hentet fra GHQ20, om depresjon, søvnvansker, og problemer med mestring av vanskeligheter. I multivariate tverrsnittsanalyser fant vi at psykiske plager var korrelert med å være enslig, hyppig bruk av alkohol, storrøyking, og hos menn, mangel på fysisk aktivitet. Familiens økonomi under oppveksten, som har vist seg viktig for hjerte-kar-sykdommer, var også korrelert med psykiske plager ${ }^{10}$.

I Finnmark III ble sammenhengen mellom religiøs tilhørighet og psykisk helse analysert ${ }^{11}$. Medlemmer av statskirken skåret best på alle de 7 variablene for psykisk helse som ble analysert, sammenlignet med de som ikke var medlemmer av noe kirkesamfunn og læstadianerne. Det er uklart om funnet skyldes at religiøs tilhørighet påvirker psykisk helse eller omvendt (seleksjon), eller andre bakenforliggende variabler det ikke er kontrollert for, eller om funnene simpelthen betyr at "den gyldne middelvei" er det beste, slik som på mange andre områder.

\section{Prospektive studier}

Utviklingen av befolkningens psykiske helse over tid I Finnmarksundersøkelsene har det vært mulig å følge utviklingen av befolkningens psykiske helse i tidsrommet 1987-97 (Finnmark III - Finnmark V), ved å koble flere av undersøkelsene ${ }^{12}$. Den populasjonen som er studert er alle personer mellom 40 og 62 år som var undersøkt med de samme spørsmålene på 3 tidspunkt (1987, 1990 og 1993). Analysene er delvis gjort ved å betrakte de tre undersøkelsene som separate tverrsnittstudier, dels ved å bruke analysemetoder for repeterte målinger hvor man følger kohorten over tid. Resultatene viser at på alle de 7 mål som ble brukt for psykisk helse ble det registrert en bedring i befolkningens psykiske helse. Dette gjaldt ved begge måter å betrakte undersøkelsene på, og ved korreksjon for alder, kjønn og utdanningslengde. Resultatene ble diskutert i lys av at det rundt 1990 var en stor krise i fiskerinæringen i fylket.

Sammenhengen mellom psykisk helse, sosialt nettverk og sosial støtte er også undersøkt prospektivt i Finnmarksundersøkelsene. To hovedhypoteser eksisterer - "direkte effekt hypotesen" ( som postulerer at sosialt nettverk/sosial støtte i seg selv påvirker psykisk helse uavhengig av psykisk stress) og "bufferhypotesen" (som postulerer at sosialt nettverk/sosial støtte i hovedsak virker ved å bufre stress). De to hypotesene ble testet i populasjonen fra de 5 kystkommunene hvor alle mellom 20 og 62 år var innkalt, og blant de som hadde svart på de aktuelle spørsmålene på to eller tre 
tidspunkt. Sammenhengen mellom sosialt nettverk, sosial støtte og mental helse ble modellert ved hjelp av Structural Equation Modelling teknikk. Vi fant lite holdepunkter for direkte-effekthypotesen ${ }^{13}$. Vi har senere også testet bufferhypotesen, og den fant støtte i vårt materiale, både for stress totalt, og særlig $\mathrm{i}$ forhold til stress i forbindelse med arbeid ${ }^{14}$.

I tidligere tverrsnittsstudier av befolkninger har det vært vist en korrelasjon mellom humør og fysisk aktivitet. Det har vært antatt en kausal sammenheng; at fysisk aktivitet forbedrer humøret; uten at dette har vært overbevisende dokumentert. I Finnmarksundersøkelsene ble dette undersøkt prospektivt ved hjelp av Structural Equation Modelling ${ }^{15}$. Resultatene bekrefter at fysisk aktivitet og humør korrelerer på hvert undersøkelsestidspunkt. Prospektivt var det imidlertid bare fysisk aktivitet $\mathrm{i}$ fritiden som hadde en svak positiv innvirkning på humøret på neste undersøkelsestidspunkt, og dette gjaldt bare for undergruppen av individer som hadde stillesittende arbeide. Vår konklusjon var derfor at longitudinelle effekter var svært små og inkonsistente.

\section{Prediktorer for utvikling av alvorlig psykisk lidelse}

Vi har under ferdigstilling prospektive analyser av utvikling av alvorlig psykiske lidelser i materialet fra Tromsø II. Som proxy for nyoppstått alvorlig psykiatrisk lidelse bruker vi da førstegangsinnleggelse på Åsgård sykehus, ved å koble pasientregisteret for avdelingen med datafila fra Tromsø II. Det var 20687 personer bosatt i Tromsø i 1980 som ikke hadde vært innlagt før, og disse ble fulgt $\mathrm{i}$ innleggelsesregisteret $\mathrm{i}$ 18 år, noe som sammenlagt ga 292378 personår. Det er gjort multvariate analyser som tar observasjonstiden for hver enkelt person $\mathrm{i}$ betraktning. Våre foreløpige resultater er dels bekreftende, dels noe avvikende fra tidligere risikofaktor-undersøkelser internasjonalt, som nesten utelukkende er tverrsnittsstudier.

\section{Sesongavhengige psykiske plager (sovn og depresjon)}

Dette har vi studert i flere ulike materialer. Fra Tromsø II i 1980 hadde vi data på depresjon fra før begrepet vinterdepresjon ble lansert i 1984. Vi analyserte nesten 8000 personer som besvarte spørreskjemaene i perioden oktober til januar, og ble overrasket over å finne en prevalens av depresjon som ikke var høyere enn det som var dokumentert fra langt mer sydlige breddegrader, ca. $10 \%{ }^{16}$. I Sør-Varanger undersøkelsen ble heller ikke prevalensen av vinterdepresjon noe høyere enn den vanlige prevalensen av depresjon som man finner $i$ de fleste generelle befolkningsstudier. Prevalensen var $5 \%$ hos menn og 11\% hos kvinner. Det dominerende problem i mørketiden var søvnproblemer, med 11\% hos menn og $20 \%$ hos kvinner ${ }^{17}$.

I Finnmark III fant vi at prevalensen av vinterdepresjon var på samme relativt lave nivå, og prevalensen av aktuell depresjon innenfor to uker før undersøkelsen var høyest om våren, ikke om vinteren ${ }^{18}$.
I Svalbardundersøkelsene svarte både den norske og den russiske populasjonen på spørsmål om sesongbetinget depresjon og søvnvansker. Ettersom det spesielt på russisk side var ufullstendig besvarelse på spørreskjemaet SPAQ, ble sammenligningen av depresjon $\mathrm{i}$ de to befolkningene gjort på bakgrunn av besvarelse på depresjon generelt. Totalt rapporterte russerne 3-4 ganger hyppigere depresjon enn det nordmenn gjorde, og for depresjon i mørketiden var prevalensen hele 5 ganger større hos russerne ${ }^{19}$. Samme forskjeller i prevalens fremkom også for søvnvansker ${ }^{20}$. Dette til tross for at begge populasjoner levde under samme klima og lysforhold.

I foreløpige analyser fra Arkhangelsk-studien rapporterer $0,7 \%$ av mennene og 3,5\% av kvinnene at de er plaget med vinterdepresjon målt med SPAQ. Dette er svært lave tall i internasjonal sammenheng. Samlet sett svekker våre studier begrepet $\mathrm{SAD}$ som et valid depresjons-fenomen, og den antatte kausale koblingen til mangel på dagslys.

\section{Alkoholrelaterte studier}

Determinanter for og distribusjonen av gammaglutamyl-transferase (GGT) ble beskrevet med data fra Tromsø III ${ }^{21}$. I en prospektiv undersøkelse 7 år senere ble determinantene for endring i GGT beskrevet ${ }^{22}$. Ansvarlig for endring i GGT-nivå var hos menn først og fremst endring i kroppsvekt, alkoholinntak og konsum av kokekaffe, mens det hos kvinner var endring $\mathrm{i}$ kroppsvekt og blodtrykk samt menopause og påbegynt bruk av p-piller. Den positive prediktive verdi (PPV) for et daglig alkoholkonsum tilsvarende 2 og 3 pils (1,5 og 2 pils for kvinner) ble kalkulert for ulike GGTnivå og ulik konsumfrekvens ${ }^{23}$. PPV hos menn økte fra 0,49 til 0,88 med økende GGT-nivå og økende drikkefrekvens, tilsvarende tall for kvinner var 0,34 og 0,75.

Ved hjelp av GGT-nivå og selvrapportert alkoholkonsum ble deretter personer med "at risk consumption" identifisert. Risikopopulasjonen fremviste signifikant større grad av psykiske lidelser som søvnproblemer og nervøsitet, og brukte mer psykofarmaka. I en påfølgende randomisert kontrollert intervensjonsstudie av ca. 350 risikokonsumenter hadde deltakerne redusert sitt konsum av alkohol med mer enn $50 \%$ etter 1 år, samtidig var GGT nivået signifikant redusert ${ }^{24}$. I kontrollgruppen derimot hadde både GGT og alkoholkonsumet steget signifikant. Et interessant aspekt ved denne intervensjonen var den positive måten den ble mottatt på av deltakerne samt den høye deltakerprosenten (99\% ved intervensjon, 96\% ved follow-up). Ved en follow-up studie 9 år senere (Tromsø IV) hadde effekten av intervensjonen ikke bare holdt seg, men var ytterlig forsterket ${ }^{25}$.

Lavt selen og vitamin E har vært postulert å ha betydning for leverskade hos høykonsumenter av alkohol. I en undersøkelse av risikokonsumenter av alkohol var nivået av selen signifikant lavere enn hos matchede normale kontroller. Vitamin E-nivået var også lavere 
hos alkoholdrikkerne, men forskjellen var ikke statistisk signifikant ${ }^{26}$.

I Svalbardstudien ønsket man å se på sammenhengen mellom selvrapportert alkoholkonsum og faktisk konsum. Ved å sammenholde selvrapportering med reliable salgsdata (nøye registrering fra salgsmyndighetenes side, ingen smugling eller hjemmebrenning) fremkom det at selvrapport bare redegjorde for ca. $40 \%$ av salgsvolumet ${ }^{27,28}$. Dette er klart mindre enn vist $\mathrm{i}$ andre studier. Den norske befolkningen på Svalbard drakk gjennomsnittlig vel 1,5 ganger mer enn befolkningen på fastlandet når selvrapport legges til grunn for konsumet. Legges derimot salgstallene til grunn var konsumet 3-4 ganger høyere for Svalbardpopulasjonen ${ }^{29}$. Helsemessig kom imidlertid Svalbardbefolkningen klart bedre ut enn fastlandsbefolkningen. Forklaringen på dette er antagelig den sterke seleksjonen av "supernormale" individer som skjer forut for, og også etter, flytting til Svalbard.

I et tilfeldig utvalg av Svalbardpopulasjonen (100 personer) ble sensitivitet, spesifisitet og likelihoodratio estimert for GGT, carbohydrate-deficient transferrin (CDT) og mitochondriell ASAT (mAST). De 2 sistnevnte markører for alkoholbruk var av interesse å teste ut og sammenligne med GGT idet de var beskrevet med særdeles høy sensitivitet og spesifisitet. Analysene avslørte imidlertid at mAST var svært lite egnet som alkoholmarkør i en populasjonsstudie som denne, mens CDT hadde en presisjon omtrent som $\mathrm{GGT}^{30}$. I tre senere studier med data fra Tromsø, Bergen og Tyskland ble igjen presisjonen til CDT sammenlignet med GGT. Disse undersøkelsene bekreftet tidligere funn fra Svalbardstudien selv om CDT kom litt bedre ut enn tidligere vist ${ }^{31-33}$.

I den russiske delen av Svalbardstudien ble samtlige blodprøver (lipider, enzymer) analysert parallelt i Tromsø og i Arkhangelsk. Dette ble ansett som viktig i det man hadde planer om videre vitenskapelig samarbeid med forskere fra Arkhangelsk. Analyseresultatene viste såpass stor divergens mellom de to laboratoriene at sammenligning var umulig ${ }^{34}$. Resultater fra den nylige gjennomførte Arkhangelskstudien viste samme divergens. Vår konklusjon er derfor at det fortsatt vil være behov for å analysere blodprøver i Norge ved felles vitenskapelige studier i Russland.

Datainnsamlingen i Arkhangelskstudien er relativt nylig avsluttet, og en resultatoversikt fra samtlige inkluderte variabler er under ferdigstillelse i ISMs skriftserie $^{35}$. Preliminære resutater viser at GGT-nivået er mer enn dobbelt så høyt som i Tromsø-III undersøkelsen, og funnet bekreftes av høy score både på CAGE og på AUDIT (spørreskjema om alkoholforbruk). Lineær regresjonsanalyse viser signifikant sammenheng mellom forhøyet GGT, høy AUDIT-score og høy CAGE-score på den ene siden og økt risiko for hjerte-kar-sykdom på den andre siden. Konsum av sprit er sterkt positivt assosiert til både CAGE- og AUDIT-score, men angivelse av gjennomsnittlig inntak synes beheftet med betydelig underrapportering.
Spesielt de eldre scoret lavt på livskvalitet og sosioøkonomiske forhold. Intervensjon mot risiko for hjerte-kar-sykdom, mot hyperlipidemi, hypertoni og mot risiko-konsum av alkohol er i gang, og oppfølgingsstudier er planlagt for neste år.

I the Harborview Injury Study ble sammenhengen mellom alkoholkonsum og fysisk skade belyst. Studien bekreftet gyldigheten av hypotesen om at jo sterkere påvirket man er av alkohol, dess mindre blir skaden ("the drunk can roll with the punches"), men bare hos menn $^{36}$. Man fant også at spørreskjemaet CAGE korrelerte bedre med et sett av biologiske markører i denne skadepopulasjonen enn tilfellet var for The Small Michigan Alcohol Screening Test (SMAST) ${ }^{37}$. En ny test (WAM) bestående av flere vektede biologiske markører ble etablert, og testet ut i det sammen materiale $^{38}$. Testen ble vurdert som et nyttig alternativ for å identifisere alkoholmisbruk i en skadepopulasjon.

\section{DISKUSJON}

Epidemiologiske studier av psykiske lidelser er vanskelige og ressurskrevende, av flere grunner. De alvorligste lidelsene har lav insidens i befolkningen, og det er vanskelig å få store nok representative utvalg $\mathrm{i}$ populasjonsstudier til å kunne studere slike lidelser. I prospektive studier må man ofte vente svært lenge for å få nok tilfeller av de forskjellige lidelsene. I studier som fokuserer på psykiske lidelser vil det ofte være vanskelig å få tak i de som har mest plager, fordi disse vanligvis har enda lavere oppmøte til slike undersøkelser enn til generelle helseundersøkelser. Det siste gjelder også personer med høyt rusmiddelforbruk. Om man derimot samler informasjon omkring ulike medisinske tilstander hvor psykisk helse og rus bare utgjør en liten del av hele studien, vil sjansene for å få høyere svarprosent og mer pålitelige data være større. Det er denne strategien vi har valgt, selv om svakheten ved våre design har vært at vi har måttet begrense antall spørsmål om psykisk helse sterkt.

En annen strategi for å få tak i nok psykiatriske tilfeller, er å benytte registre over personer som allerede er blitt klassifisert som psykisk lidende, og innhente relevante tilleggsopplysninger ved koblinger til andre helseregistre. Denne strategien er også viktig i epidemiologi, men etter at Sentralregisteret for psykoser ble stengt for nye data fra 1987, har dette vært lite benyttet i Norge. Tidligere studier fra Psykoseregisteret, og våre nyere mortalitetsstudier med utgangspunkt $\mathrm{i}$ registeret for Åsgård sykehus viser hvor nyttige slike registre er. Det må være en viktig oppgave for det norske epidemiologiske miljøet å bidra til at vi på nytt făr en landsomfattende registrering av psykiske lidelser på lik linje med de somatiske.

I Norge for øvrig har det i de senere årene vært gjennomført og planlagt flere store epidemiologiske befolkningsstudier hvor psykiatri inngår som delaspekter i studiene, for eksempel HUNT, HUSK og HUBRO. Dette betyr at flere psykiatriske miljøer etter 
hvert vil få tilgang på tilsvarende store datamaterialer som vi inntil for få år siden var nokså alene om. I tillegg vil reorganiseringen av statlig helseforvaltning med samling av flere store epidemiologiske miljøer $\mathrm{i}$ Oslo i Nasjonalt Folkehelseinstitutt, der psykiatri også skal inngå, trolig få store konsekvenser for de mindre miljøene utenfor Oslo. I denne situasjonen har vi diskutert hvilken strategi vi skal legge oss på for framtiden. Vi vil selvsagt fortsette å analysere nye problemstillinger i de store datamengdene vi har, både som repeterte tverrsnittsstudier og prospektivt ved å koble de sammen, og fortsette å delta i planlegging og utforming av fremtidige befolkningsstudier i NordNorge og i Russland. Spesielt samarbeidet med Universitetet i Arkhangelsk vil vi prioritere høyt, fordi russerne trenger hjelp til å bygge opp sin epidemiologiske forskning, og fordi folkehelseproblemene er så store. Men i tillegg vil vi trolig ha størst potensiale ved å forsøke å utnytte de komparative fortrinn vi har ved å være verdens nordligst beliggende universitet og de spesielle forhold som eksisterer i vår landsdel. Dette innebærer en fokusering på psykiske helseplager knyttet til årstidsvariasjoner og biorytmer, hvor vi befinner oss $i$ et "naturlig laboratorium" med bl.a. 2 måneders mørketid og tilsvarende lang midnattsoltid. Dessuten er den nord-norske befolkningen multietnisk, med et betydelig innslag av urbefolkning (samer), i tillegg til andre etniske grupper som kvener og russere. Disse ulike etniske grupper og deres situasjon som minoritetsgrupper i det norske samfunn representerer trolig annen type problematikk enn den som innvandrere, flyktninger og asylsøkere representerer. Dette gir unike muligheter for transkulturell psykiatrisk forskning. Et tredje, stort sett uutforsket område, er psykiske langtidsvirkninger av krigsopplevelser, noe som særlig befolkningen i Finnmark var eksponert for under siste verdenskrig. Mulighetene for å drive god og original psykiatrisk epidemiologisk forskning med utgangspunkt $\mathrm{i}$ disse spesielle forholdene i tiden fremover vil være store. Vi finner det rimelig at denne forskningen foregår ved det universitet som har sine røtter i den nord-norske virkeligheten.

\section{REFERANSER}

1. Forsdahl A, Fylkesnes K, Lund E, Lupton B, Selmer R, Straume E. Hjerte-kar-undersøkelsene i Finnmark 1974-2000. Tromsø: Institutt for Samfunnsmedisin, Universitetet i Tromsø, 2000.

2. Goldberg D. The detection of psychiatric illness by questionnaire. London: Oxford University Press, 1972.

3. Schirmer H, Høyer G, Nilssen O, Brenn T, Steine S. Helse og livskvalitet på 78 grader nord. Rapport fra en befolkningsstudie på Svalbard høsten 1988. Tromsø: Institutt for Samfunnsmedisin, 1997.

4. Jacobsen BK, Hasvold T, Høyer G, Hansen V. The General Health Questionnaire: how many items are really necessary in population surveys? Psychol Med 1995; 25: 957-61.

5. Lund E, Hansen V. Responses to the Seasonal Pattern Assessment Questionnaire in different seasons. Am J Psychiatry 2001; 158: 316-8.

6. Hansen V, Jacobsen BK, Arnesen E. Prevalence of serious psychiatric morbidity in attenders and nonattenders to a health survey of a general population. Am J Epidemiol 2001; 154: 891-4.

7. Høye A, Hansen V, Olstad R. First-admission schizophrenic patients in northern Norway, 1980-95: Sex differences in diagnostic practice. Nord J Psychiatry 2000; 54: 319-25.

8. Hansen V, Arnesen E, Jacobsen BK. Total mortality in people admitted to a psychiatric hospital. $B r J$ Psychiatry 1997; 170: 186-90.

9. Hansen V, Jacobsen BK, Arnesen E. Cause specific mortality in psychiatric patients after deinstitutionalisation. Br J Psychiatry 2001; 179: 438-43.

10. Hansen V, Jacobsen BK. Mental distress and social conditions and lifestyle in northern Norway. BMJ 1989; 299: $85-8$.

11. Årnes SM, Kleiven M, Olstad R, Fønnebø V. Religiøs tilhørighet og psykisk helse - finnes det en sammenheng? Helseundersøkelsen i Finnmarrk 1990. Tidsskr Nor Lageforen 1996; 116: 3598-601.

12. Olstad R, Søgaard AJ, Sexton H. Mental helse i kyst-Finnmark. Tidsskr Nor Laegeforen 1998; 118: 8-13.

13. Olstad R, Sexton H, Søgaard AJ. The Finnmark study. Social support, social network and mental distress in a prospective population study. Soc Psychiatry Psychiatr Epidemiol 1999; 34: 519-25.

14. Olstad R, Sexton H, Søgaard AJ. A prospective population study of the social support buffer hypothesis, specific stressors and mental distress. Soc Psychiatry Psychiatr Epidemiol 2001; 36: 582-9.

15. Sexton H, Søgaard AJ, Olstad R. How are mood and exercise related? Results from the Finnmark study. Soc Psychiatry Psychiatr Epidemiol 2001; 36: 348-53.

16. Hansen V, Jacobsen BK, Husby R. Mental distress during winter. An epidemiological study of 7759 adults north of Arctic Circle. Acta Psychiatr Scand 1991; 84: 137-41.

17. Hansen V, Lund E, Smith-Sivertsen T. Self-reported mental distress under the shifting daylight in the high north. Psychol Med 1998; 28: 447-52. 
18. Reitan ECK. Mørketidsproblem i Finnmark. Åbo: Institusjonen for Psykologi, Universitetet i Åbo, 1999.

19. Nilssen O, Brenn T, Høyer G, Lipton R, Boiko J, Tkatchev A. Self-reported seasonal variation in depression at 78 degree north. The Svalbard Study. Int J Circumpolar Health 1999; 58: 14-23.

20. Nilssen O, Lipton R, Brenn T, Høyer G, Boiko E, Tkatchev A. Sleeping problems at 78 degrees north: the Svalbard Study. Acta Psychiatr Scand 1997; 95: 44-8.

21. Nilssen O, Førde OH, Brenn T. The Tromso Study. Distribution and population determinants of gammaglutamyltransferase. Am J Epidemiol 1990; 132: 318-26.

22. Nilssen O, Førde OH. Seven-year longitudinal population study of change in gamma-glutamyltransferase: the Tromso Study. Am J Epidemiol 1994; 139: 787-92.

23. Nilssen O, Førde OH. The Tromso Study: the positive predictive value of gamma-glutamyltransferase and an alcohol questionnaire in the detection of early-stage risk drinkers. J Intern Med 1991; 229: 497-500.

24. Nilssen O. The Tromso Study: identification of and a controlled intervention on a population of early-stage risk drinkers. Prev Med 1991; 20: 518-28.

25. Nilssen O. Long term effect of brief intervention on alcohol in risk drinkers; an eight year follow-up study. BMJ 2002.

26. Ringstad J, Knutsen S, Nilssen O, Thomassen Y. A comparative study of serum Selenium and Vitamin E level in a population of male risk drinkers and abstainers. Biological Trace Element Research 1993; 36: 65-71.

27. Høyer G, Nilssen O, Brenn T, Schirmer H. The Svalbard study 1988-89: a unique setting for validation of self-reported alcohol consumption. Addiction 1995; 90: 539-44.

28. Høyer G, Nilssen O, Brenn T, Schirmer H. Påliteligheten av selvrapportert alkoholkonsum. Svalbardstudien 1988-89. Norsk Epidemiologi 1996; 6: 109-13.

29. Høyer G, Nilssen O, Brenn T, Schirmer H. Nordmenn og billig alkohol. Alkoholkonsum i et norsk lavprisområde. Nordisk Alkoholtidsskrift 1994; 3: 139-45.

30. Nilssen O, Huseby NE, Høyer G, Brenn T, Schirmer H, Førde OH. New alcohol markers - how useful are they in population studies: the Svalbard Study 1988-89. Alcohol Clin Exp Res 1992; 16: 82-6.

31. Huseby NE, Nilssen O, Kanitz RD. Evaluation of two biological markers combined as a parameter of alcohol dependency. Alcohol Alcohol 1997; 32: 731-7.

32. Huseby NE, Bjordal E, Nilssen O, Barth T. Utility of biological markers during outpatient treatment of alcohol-dependent subjects: carbohydrate-deficient transferrin responds to moderate changes in alcohol consumption. Alcohol Clin Exp Res 1997; 21: 1343-6.

33. Huseby NE, Nilssen O, Erfurth A, Wetterling T, Kanitz RD. Carbohydrate-deficient transferrin and alcohol dependency: variation in response to alcohol intake among different groups of patients. Alcohol Clin Exp Res 1997; 21: 201-5.

34. Nilssen O, Lipton R, Høyer G, Bojko J, Tkatchev A, Brenn T. Blood serum analyses in population studies: parallel analyses and degree of agreement in a Norwegian-Russian co-project. The Svalbard Study. Arctic Med Res 1996; 55: 75-82.

35. Nilssen O, Brenn T, Brox J, et al. The Arkhangelsk Study 2000: Alcohol drinking and its impact on health in the north of Russia. Tromsø: Institute of Community Medicine, 2002.

36. Nilssen O, Ries R, Rivara FP, Gurney JG, Jurkovich GJ. Alcohol and trauma: The impact of acute and chronic alcohol abuse on injury severity and death in a trauma population. Norsk Epidemiologi 1996; 6: 103-8.

37. Nilssen O, Ries RK, Rivara FP, Gurney JG, Jurkovich GJ. The CAGE questionnaire and the Short Michigan Alcohol Screening Test in trauma patients: comparison of their correlations with biological alcohol markers. $J$ Trauma 1994; 36: 784-8.

38. Nilssen O, Ries R, Rivara FP, Gurney JG, Jurkovich GJ. The "WAM" score: sensitivity and specificity of a user friendly biological screening test for alcohol problems in trauma patients. Addiction 1996; 91: 255-62. 